\title{
Effects of Polycyclic Aromatic Hydrocarbons on Sexual Maturity of Atlantic cod, Gadus morhua, Following Chronic Exposure
}

\author{
R. A. $\operatorname{Khan}^{1}$ \\ ${ }^{1}$ Department of Biology, Memorial University of Newfoundland, St. John's, Canada \\ Correspondence: R. A. Khan, Department of Biology, Memorial University of Newfoundland, St. John's, \\ Newfoundland, A1B 3X9, Canada. Tel: 1-709-739-8986. E-mail: rakhan@mun.ca
}

Received: June 18, 2012 Accepted: July 9, 2012 Online Published: August 16, 2012

doi:10.5539/ep.v2n1p1 URL: http://dx.doi.org/10.5539/ep.v2n1p1

\begin{abstract}
Mature Atlantic cod, Gadus morhua, were exposed in an ambient flow-through sea water system to low concentrations of water-accommodated fractions (WAFs) of a crude oil for periods of 38-92 days to ascertain its effects on sexual maturity. Some exposed groups were depurated after exposure for 4 to 287 days. Minimal mortality but a greater percentage of skin and gill lesions and a reduction in weight gained, especially in females, occurred in the WAF-exposed cod in contrast to controls in summer-autumn. The WAFs also disrupted gonadal development and delayed spawning and spermiation although the fish were fed to satiation. Sexual development was also interrupted following exposure to the WAFs and depuration afterwards. These results suggest that polycyclic aromatic hydrocarbons in the water column can potentially disrupt reproduction in Atlantic cod and eventually affect inshore populations inhabiting the cold subarctic waters in Newfoundland and Labrador in event of a major oil spill from offshore wells or supertankers.
\end{abstract}

Keywords: polycyclic hydrocarbons, sexual maturity, Atlantic cod

\section{Introduction}

Pollutants, including polycyclic aromatic hydrocarbons (PAHs) derived from crude oil, have been reported to affect reproduction in fish by disrupting endocrine function (Kime, 1995). PAHs are composed of a complex mixture of organic compounds especially the polyaromatic components that are stable, lipophobic, capable of accumulating in tissues and are toxic to organisms (Tuvikene, 1995; Lee \& Page, 1997; Barron et al., 2004). Chronic exposure to PAHs caused a reduction in gonad size in cunner (Tautogolabrus adspersus) and winter flounder (Pleuronectes $=$ Pseudopleuronectes americanus) whereas acute exposure of Atlantic salmon (Salmo salar) resulted in decreased plasma androgens (Payne et al., 1978; Fletcher et al., 1982; Truscott et al., 1983). It appeared that PAHs disrupted endocrine function in teleosts by altering testicular steroid production (Evanson $\&$ Van Der Kraak, 2001; Tetreault et al., 2009). Additionally, Dolly Varden (Salvelinus malma) sampled in 1989 following the Exxon Valdez oil spill were projected to have depressed 19ß-estradiol compared to 1990 samples (Sol et al., 2000). Moreover, depuration of longhorn sculpin (Myoxocephalus octodecemspinosus), after chronic exposure to oil-contaminated sediment, revealed that gonadal development was disrupted (Khan, 1991). It is evident that PAHs cause impairment, altered energetic and reproductive effects in fish (Kime, 1995; Lee \& Page, 1997).

Little is known of the effects of water-accommodated fractions (WAFs) of crude oil in the water column on reproduction of sexually mature Atlantic cod exposed at different times of the year. While populations offshore near Newfoundland and Labrador have declined as a result of climatic changes and over exploitation, spawning stocks still exist inshore (Rideout \& Rose, 2006). The Labrador current encompasses a wide margin of cold water that flows over both inshore and offshore areas where two oil wells are currently located (Sutcliffe et al., 1983). Spills and seeps are known to occur during drilling operations at oil wells and potential exposure of fish living in the water column can occur (Lee \& Page, 1997). Although most oil spills tend to occur offshore, the long-term effects appear to be inshore when the oily residue contaminates intertidal areas (Jewett et al., 2002). There is, currently, a paucity of Atlantic cod and fish as prey in both inshore and offshore areas. In event of a major spill and use of dispersants to emulsify surface slicks, additional PAHs will be released into the water 
column and impact on all marine organisms. Consequently, the use of dispersants following an oil spill could also have a negative impact on fish inhabiting subtidal areas (Khan \& Payne, 2005; Lyons et al., 2011). The persistence of oil in subtidal areas for decades without change, as observed after the Exxon Valdez spill, have a profound effect on inshore cod populations by disrupting reproduction.

Induction of the reproductive cycle of Atlantic cod in the northwestern Atlantic Ocean commences in autumn and culminates with spawning during late winter-spring (W. Scott \& M. Scott, 1988). Some stocks of cod remain permanently inshore while others in offshore locations migrate inshore in summer to feed on capelin (Mallotus villosus) and subsequently move offshore in autumn (Templeman, 1974). A previous laboratory study reported that long-term exposure to water-accommodated-fractions (WAFs) of crude oil disrupted gametogenesis in male cod (Kiceniuk \& Khan, 1987). Another study noted that cod succumbed to the WAFs when infected with a hemoflagellate that occurred widely in fish on the continental shelf (Khan, 1987). Since there is a potential of additional oil spills from two oil wells currently operating off coastal Newfoundland, the present study was designed to investigate the long-term effect of low levels of WAFs on gonadal maturation in cod, especially females that are responsible for maintaining population levels. Three month-exposure periods as used in previous studies or less was chosen to simulate the time offshore stocks remained inshore (Kiceniuk \& Khan, 1987; W. Scott \& M. Scott, 1988). An additional purpose of the study was to ascertain the influence of depuration, involving discontinued exposure to the WAFs, for variable periods following chronic exposure to WAFs. Since a previous study reported that secondary branchial lamellae of the gills were susceptible to damage by the WAFs that caused hyperplasia, thickening and fusion of adjacent filaments, these bioindicators were examined to determine the extent of the lesions and also to verify that exposure had occurred (Khan \& Kiceniuk, 1984).

Atlantic cod was chosen because of its susceptibility to WAFs, its availability, readily adaptable to laboratory conditions and its commercial importance in eastern Canada.

\section{Materials and Methods}

Adult Atlantic cod, $>4$ years (total length $45-69 \mathrm{~cm}, 5-9$ years old), were captured in traps set 5-6 meters deep in Conception Bay, $47^{\circ} 38^{\prime} \mathrm{N}, 52^{\circ} 51^{\prime} \mathrm{W}$, during the summers of 1982 to 1990 and held in raceways, $14 \times 2 \times 1 \mathrm{~m}$, supplied with ambient running seawater for 6 to 24 weeks prior to exposure to adjust to laboratory conditions at the Ocean Sciences Centre. The fish were fed to satiation, freshly-thawed capelin, three times weekly from spring to autumn but less often during winter when feed intake declined. Unconsumed feed was removed on the following day. Fish free of external abnormalities were weighed, measured, tagged with spaghetti tags and placed in $3000 \mathrm{~L}$ flow-through tanks $(11.0 \times 2.5 \times 1.2 \mathrm{~m})$ supplied with air and ambient running seawater. Both control and oil-treated fish were held under natural daylight conditions during spring to autumn outdoor but moved indoor in winter and held under a 12-hour photoperiod regime (Table 1). Although the cod were not handled during all but two experiment (numbers $7 \&$ 8), some lost their tags. However, cod that succumbed, had retained their tags but were not included in the analysis of the data. Consequently, cod that survived in each aquarium were treated as a group when the data was analyzed. These experiments were conducted over a 9-year period. The number of fish of each sex exposed and duration of each experiment are shown in Tables 2 and 3.

Table 1. Protocol involving chronic exposure of mature Atlantic cod, G. morhua, to water-accommodated fractions of Hibernia crude oil from the Grand Banks off Newfoundland including time of year exposed, ambient water temperature, days exposed and mean ( $\overline{\mathrm{x}} \pm$ ) total hydrocarbon (ppb) concentration (THCs)

\begin{tabular}{ccccc}
\hline $\begin{array}{c}\text { Oil experiment } \\
\text { number }\end{array}$ & Time of year & $\begin{array}{c}\text { Water temperature } \\
\left({ }^{\circ} \mathrm{C}\right)\end{array}$ & Days exposed & $\overline{\mathrm{x}} \pm$ THCs \\
\hline 1 & July - October & $9-14$ & 89 & $49 \pm 16$ \\
2 & August - November & $10-14$ & 86 & $42 \pm 19$ \\
3 & September - November & $10-14$ & $92(131)^{*}$ & $40 \pm 12$ \\
4 & November - February & $0-2$ & $86(111)^{*}$ & $31 \pm 14$ \\
5 & December - February & $0-2$ & $86(157)^{*}$ & $15 \pm 10$ \\
6 & April - May & $1-3$ & 38 & $22 \pm 12$ \\
7 & June - June & $6-12$ & $90(287)^{*}$ & $28 \pm 9$ \\
8 & October - March & $0-10$ & $4(141)^{*}$ & $21 \pm 8$ \\
\hline
\end{tabular}

"Days depurated after exposure 
Table 2. Variables of sexually mature Atlantic cod, G. morhua, following chronic exposure to petroleum aromatic hydrocarbons during summer-autumn

\begin{tabular}{|c|c|c|c|c|c|c|c|c|}
\hline $\begin{array}{l}\text { Experiment } \\
\text { Number }\end{array}$ & Sex & $\begin{array}{l}\text { Fish } \\
\text { Group }\end{array}$ & $\begin{array}{c}\text { Number } \\
\text { Survived/ } \\
\text { Exposed }\end{array}$ & $\begin{array}{l}\text { Initial } \\
\text { Length }\end{array}$ & $\begin{array}{l}\text { Initial } \\
\text { Weight }\end{array}$ & $\begin{array}{l}\text { \% Weight } \\
\text { Change }\end{array}$ & $\begin{array}{l}\text { Final } \dagger \text { K-F } \\
\left(\times 10^{-4}\right)\end{array}$ & $\begin{array}{l}\text { G.S.I. }^{*} \\
\left(\times 10^{-4}\right)\end{array}$ \\
\hline \multirow{4}{*}{1} & \multirow{2}{*}{$\mathrm{F}$} & Control & $11 / 11$ & $52 \pm 1$ & $971 \pm 74$ & $+71 \pm 12^{* *}$ & $79 \pm 10$ & $56 \pm 5^{* *}$ \\
\hline & & Oil & $10 / 10$ & $53 \pm 1$ & $954 \pm 61$ & $+15 \pm 5$ & $82 \pm 11$ & $16 \pm 2$ \\
\hline & \multirow{2}{*}{$\mathrm{M}$} & Control & $10 / 10$ & $52 \pm 1$ & $928 \pm 38$ & $+49 \pm 10$ & $79 \pm 10$ & $89 \pm 7^{* *}$ \\
\hline & & Oil & $10 / 10$ & $51 \pm 1$ & $972 \pm 41$ & $+24 \pm 7$ & $74 \pm 9$ & $13 \pm 2$ \\
\hline \multirow{4}{*}{2} & \multirow{2}{*}{$\mathrm{F}$} & Control & $14 / 14$ & $48 \pm 1$ & $911 \pm 41$ & $+44 \pm 6^{* *}$ & $107 \pm 12$ & $178 \pm 9^{* *}$ \\
\hline & & Oil & $12 / 14$ & $50 \pm 1$ & $1017 \pm 64$ & $+14 \pm 3$ & $81 \pm 9$ & $106 \pm 7$ \\
\hline & \multirow{2}{*}{$\mathrm{M}$} & Control & $14 / 14$ & $50 \pm 1$ & $930 \pm 38$ & $+46 \pm 7$ & $95 \pm 10$ & $188 \pm 12^{* *}$ \\
\hline & & Oil & $12 / 14$ & $48 \pm 1$ & $959 \pm 43$ & $+33 \pm 5$ & $94 \pm 10$ & $67 \pm 4$ \\
\hline \multirow{4}{*}{3} & \multirow{2}{*}{$\mathrm{F}$} & Control & $10 / 10$ & $49 \pm 1$ & $906 \pm 41$ & $-2 \pm 2$ & $74 \pm 10$ & $29 \pm 6$ \\
\hline & & Oil & $11 / 11$ & $49 \pm 1$ & $827 \pm 38$ & $-17 \pm 7$ & $59 \pm 7$ & $15 \pm 5$ \\
\hline & \multirow{2}{*}{ M } & Control & $10 / 10$ & $52 \pm 1$ & $1201 \pm 87$ & $-4 \pm 4$ & $85 \pm 12$ & $53 \pm 6^{* *}$ \\
\hline & & Oil & $8 / 9$ & $51 \pm 1$ & $1115 \pm 78$ & $-9 \pm 5$ & $77 \pm 10$ & $11 \pm 4$ \\
\hline \multirow{4}{*}{4} & \multirow{2}{*}{$\mathrm{F}$} & Control & $11 / 11$ & $54 \pm 1$ & $1061 \pm 89$ & $+6 \pm 5$ & $70 \pm 9$ & $73 \pm 5^{* *}$ \\
\hline & & Oil & $9 / 11$ & $49 \pm 1$ & $1232 \pm 97$ & $-14 \pm 0$ & $71 \pm 8$ & $28 \pm 3$ \\
\hline & \multirow{2}{*}{$\mathrm{M}$} & Control & $10 / 10$ & $56 \pm 1$ & $1273 \pm 101$ & $+8 \pm 5$ & $76 \pm 11$ & $182 \pm 14^{* *}$ \\
\hline & & Oil & $9 / 10$ & $54 \pm 1$ & $1225 \pm 96$ & $-17 \pm 11$ & $64 \pm 8$ & $49 \pm 5$ \\
\hline \multirow{4}{*}{5} & \multirow{2}{*}{$\mathrm{F}$} & Control & $10 / 10$ & $46 \pm 1$ & $906 \pm 69$ & $37 \pm 6$ & $74 \pm 11$ & $30 \pm 3$ \\
\hline & & Oil & $11 / 11$ & $46 \pm 1$ & $982 \pm 77$ & $12 \pm 4$ & $59 \pm 10$ & $15 \pm 2$ \\
\hline & \multirow{2}{*}{ M } & Control & $10 / 10$ & $48 \pm 2$ & $1001 \pm 86$ & $42 \pm 10$ & $85 \pm 14$ & $53 \pm 5^{* *}$ \\
\hline & & Oil & $8 / 9$ & $48 \pm 2$ & $1028 \pm 91$ & $16 \pm 7$ & $77 \pm 11$ & $11 \pm 1$ \\
\hline \multirow{4}{*}{6} & \multirow{2}{*}{$\mathrm{F}$} & Control & $13 / 13$ & $58 \pm 1$ & $1534 \pm 68$ & $+4 \pm 5$ & $76 \pm 11$ & $89 \pm 4$ \\
\hline & & Oil & $14 / 15$ & $54 \pm 1$ & $1124 \pm 74$ & $+2 \pm 2$ & $73 \pm 9$ & $87 \pm 3$ \\
\hline & \multirow{2}{*}{ M } & Control & $16 / 16$ & $58 \pm 1$ & $1551 \pm 81$ & $+7 \pm 4$ & $75 \pm 7$ & $68 \pm 3$ \\
\hline & & Oil & $13 / 14$ & $54 \pm 1$ & $1114 \pm 68$ & $+1 \pm 3$ & $74 \pm 11$ & $61 \pm 4$ \\
\hline \multirow{2}{*}{7} & \multirow{2}{*}{$\mathrm{F}$} & Control & $22 / 22$ & $43 \pm 1$ & $669 \pm 42$ & +07 & $76 \pm 3$ & $70 \pm 6$ \\
\hline & & Oil & $17 / 21$ & $44 \pm 1$ & $713 \pm 61$ & +112 & $77 \pm 5$ & $78 \pm 11$ \\
\hline \multirow{2}{*}{$8 \%$} & \multirow{2}{*}{$\mathrm{F}$} & Control & $14 / 14$ & $50 \pm 1$ & $1016 \pm 47$ & +14 & $80 \pm 6$ & $88 \pm 10^{* *}$ \\
\hline & & Oil & $14 / 14$ & $49 \pm 1$ & $961 \pm 38$ & -21 & $74 \pm 5$ & $33 \pm 7$ \\
\hline
\end{tabular}

$\dagger \mathrm{K}-\mathrm{f}=$ condition factor

${ }^{*}$ G.S.I. $=$ gonadal somatic index

${ }^{* *}=$ significantly different $(\mathrm{p} \#$ 0.05) from other group

Exposed for 4 days at concentration of 30-80 ppb 
Table 3. Prevalence (\%) of external and branchial ${ }^{*}$ lesions and predominant types of cells observed in the gonads of Atlantic cod exposed from late autumn onwards to low levels of petroleum aromatic hydrocarbons following autopsy

\begin{tabular}{|c|c|c|c|c|c|c|c|}
\hline \multirow{2}{*}{$\begin{array}{l}\text { Experiment } \\
\text { No }\end{array}$} & \multirow[t]{2}{*}{ Fish Group } & \multirow[t]{2}{*}{ Sex } & \multirow{2}{*}{$\begin{array}{l}\text { \% External } \\
\text { Lesions }\end{array}$} & \multicolumn{3}{|c|}{$\begin{array}{l}\text { \% Class Branchial } \\
\text { Lesions }\end{array}$} & \multirow[t]{2}{*}{ Cell types-Comments } \\
\hline & & & & 1 & 2 & 3 & \\
\hline \multirow{4}{*}{3} & Control & \multirow{2}{*}{$\mathrm{F}$} & 0 & 100 & & & Large developing oocytes \\
\hline & Oil & & 60 & & 11 & 89 & Imature ovaries, small oocytes \\
\hline & Control & \multirow{2}{*}{ M } & 0 & 100 & & & $\begin{array}{l}\text { Large, developing } \\
\text { spermatocytes }\end{array}$ \\
\hline & Oil & & 90 & & & 100 & $\begin{array}{l}\text { Immature testes, small } \\
\text { spermatocytes }\end{array}$ \\
\hline \multirow{4}{*}{4} & Control & \multirow[b]{2}{*}{$\mathrm{F}$} & 0 & 100 & & & Large, developing oocytes \\
\hline & Oil & & 33 & & & 100 & $\begin{array}{c}\text { Small oocytes, disrupted } \\
\text { development }\end{array}$ \\
\hline & Control & \multirow{2}{*}{$\mathrm{M}$} & 0 & 100 & & & $\begin{array}{l}\text { Large, developing } \\
\text { spermatocytes }\end{array}$ \\
\hline & Oil & & 40 & & & 100 & $\begin{array}{c}\text { Small spermatocytes, disrupted } \\
\text { development }\end{array}$ \\
\hline \multirow{4}{*}{5} & Control & \multirow[b]{2}{*}{$\mathrm{F}$} & 0 & 100 & & & Developing follicles \\
\hline & Oil & & 37 & & & 100 & $\begin{array}{c}\text { Small oocytes, disrupted } \\
\text { development }\end{array}$ \\
\hline & Control & \multirow[b]{2}{*}{ M } & 0 & 100 & & & Spermatids, few sperm \\
\hline & Oil & & 53 & & & 100 & $\begin{array}{c}\text { Small spermatocytes, disrupted } \\
\text { development }\end{array}$ \\
\hline \multirow{4}{*}{6} & Control & \multirow[t]{2}{*}{$F$} & 0 & 100 & & & $\begin{array}{l}\text { Atretic follicles, spent, } \\
\text { post-ovulatory }\end{array}$ \\
\hline & Oil & & 40 & & & 100 & Small oocytes, post-ovulatory \\
\hline & Control & \multirow{2}{*}{$\mathrm{M}$} & 0 & 100 & & & $\begin{array}{l}\text { Remnants of sperm, small } \\
\text { spermatocytes }\end{array}$ \\
\hline & Oil & & 50 & & & 100 & $\begin{array}{l}\text { Remnants of sperm, small } \\
\text { spermatocytes }\end{array}$ \\
\hline \multirow[b]{2}{*}{7} & Control & \multirow[b]{2}{*}{$\mathrm{F}$} & 0 & 100 & & & Small oocytes, interphase \\
\hline & Oil & & 57 & & & 100 & $\begin{array}{l}\text { Atretic oocytes, post-ovulatory } \\
\text { follicles, development } \\
\text { disrupted }\end{array}$ \\
\hline \multirow[b]{2}{*}{8} & Control & \multirow[b]{2}{*}{$\mathrm{F}$} & 0 & 100 & & & Maturing follicles \\
\hline & Oil & & 56 & & & 44 & $\begin{array}{l}\text { Disrupted development, small } \\
\text { oocytes }\end{array}$ \\
\hline
\end{tabular}

${ }^{*}$ Classified as none to minimal (1), moderate (2), and excessive (3) hyperplasia

The method of preparation of the WAFs was described previously (Kiceniuk \& Khan, 1987). Two hundred ml of Hibernia crude oil originating from the continental shelf from offshore Newfoundland, were placed each week in a $80 \mathrm{~L}$ head tank supplied with a 2-volt motor stirrer to ensure mixing with a constant inflow, $2 \mathrm{~L} / \mathrm{min}$, of seawater. This protocol, identical to previous studies, administered $200 \mathrm{ml}$ of crude oil weekly to the head tank (Kiceniuk \& Khan, 1987). The WAFs were drawn off from the bottom of the head tank into the aquarium housing the experimental group. Chronic exposure of the cod to the WAFs for about 12 weeks was similar to that reported in 
another study (Kiceniuk \& Khan, 1997). However, shorter exposure periods were used in two experiments (numbers 6 \& 8), especially one (number 8 ) in which the fish were depurated afterwards. Control fish were maintained similarly but without WAFs. Water samples were collected at the top and bottom of the aquarium, pooled and analyzed for the total hydrocarbon concentration about 24 hours after the introduction of the crude oil into the head tank and also the day before each experiment was concluded. Means and standard errors are based on two readings for each experiment. Total hydrocarbon concentration (THC) was determined by high performance liquid chromatography at the Department of Fisheries \& Oceans, St. John's, Newfoundland and the results expressed as $\mu \mathrm{g}$ of crude oil/L of water (ppb) (Kiceniuk \& Khan, 1987). Mean THCs in the fish tank are shown in Table 1. During the spawning period in spring, the abdomen of both sexes was compressed laterally to determine their potential to release eggs or sperm (experiments 7 and 8).

Samples of gills and gonads were removed from each fish for histological assessment. Those were fixed in $10 \%$ buffered formalin, processed by conventional histological methods and sections, $10 \mu \mathrm{m}$ in thickness, stained with hematoxylin and eosin and Mallory's triple stain for microscopic examination. Toxiopathic lesions in the secondary branchial lamellae were classified as normal to minimal hyperplasia (class 1), moderate in which hyperplasia resulted in two cell layers in thickness of the lamellae (class 2) or excessive where fusion between adjacent lamellae had occurred and included telangiectasis (dilation of the branchial blood vessels, class 3 ).

At the conclusion of each experiment, total and eviscerated body weights, total body length and gonadal weights were recorded. Percent (\%) weight change, Fulton's condition factor (weight/length ${ }^{3}$ ) and gonadosomatic index (GSI, gonad weight/eviscerated body weight) were compared between oil-treated and control groups of both sexes using a 2-way ANOVA for significant differences $(\mathrm{p}<0.05)$ for treatment, sex and sex $\mathrm{x}$ treatment interaction as the data was normally distributed. Means and standard errors were calculated for all groups.

\section{Results}

THCs in the fish tank were initially greater after addition of crude oil to the head tank but the concentration declined towards the end of the week. Additionally, concentration of the THCs was affected by the ambient water temperature, declining during late-autumn to early spring. Following the addition of crude oil and flow of the effluent containing the WAFs into the aquarium with cod, they became hyperactive during the first day. However, this behavior declined after this time and reverted to normalcy. Additions of crude oil to the head tank at weekly intervals did not induce additional hyperactivity. About 6 weeks after exposure of the cod to WAFs, some swam at the surface of the aquarium with open jaws and appeared to be gasping for air.

Differences in mortality, external lesions, percent weight change and GSIs were observed between both genders of control and PAH-treated Atlantic cod during summer to autumn (experiments $1 \& 2$ ). Percent weight change in females and GSIs in both sexes were significantly greater in control groups than in the oil-treated fish but differences in K-factor were not apparent (Table 2). Sex and treatment interaction occurred in both experiments conducted between summer and autumn but less often after this time. Mortality varied from 7 to $19 \%$ and occurred during depuration. Levels of external lesions, varying from 18 to $21 \%$, were noted in oil-treated cod in all two experiments $(1 \& 2)$ while none was apparent in the control groups. All female and male cod in these two exposures to WAFs exhibited extensive hyperplasia that resulted in increase s lamellar thickening, fusion of adjacent lamellae and capillary aneurisms. None of these lesions was observed in the controls (Table 3).

There were also differences in selected biological variables between control and oil-treated Atlantic cod after exposure between late autumn to spring (Table 2). Although mortality was low, external lesions in the skin and tail fin necrosis that varied from 33 to $57 \%$ occurred only in WAFs- exposed cod. Percent weight change and $\mathrm{K}$-factor were not significantly different between the two groups. However, the GSI of one or both sexes was significantly greater in the controls than in the oil-treated groups in five experiments $(3,4$ and 5; Table 2). Examination of histological sections of the ovaries of control cod revealed developing follicles in contrast to small oocytes in the WAF-exposed females (Table 3). Additionally, spermatocytes were larger in control males in three experiments (numbers 3, 4 and 5) than in the WAF-exposed fish. While spermatids occurred also in all the controls in two trials (numbers 4 and 5), none was seen in the oil-contaminated fish. Differences in GSIs and sex cell development were not apparent in two experiments (number 6 and 7) between both sexes of control and WAF-exposed cod (Tables 2 and 3). However, in one experiment in which the female cod were depurated for 287 days after exposure to the PAHs for 90 days, weight gained at the latter time was significantly greater in the controls than in the WAF-exposed group but not at other intervals of the trial (Figure 1). Seventeen of 22 control females with distended abdomens released spawn after compression during the first week in May while none was observed in 21 of the WAF-exposed fish (experiment 7). An additional examination conducted at the end of May resulted in the release of spawn only in 16 of 21 of the oil-exposed females but none in the spent controls. 
Comparison of histological development in the ovaries, following autopsy in June, revealed no differences as most cod had released their spawn and were in the post-ovulatory stage characterized by the presence of small oocytes. Three WAF-exposed fish were observed with post-ovulatory follicles. In a final trial in which female cod were exposed for 4 days to the PAHs and depurated for 141 days afterwards, gonadal development was disrupted as GSI values were significantly lower than in the controls (experiment 8, Table 2). Moreover, maturing follicles were observed in all of the controls in contrast to small oocytes in the PAH-exposed fish.

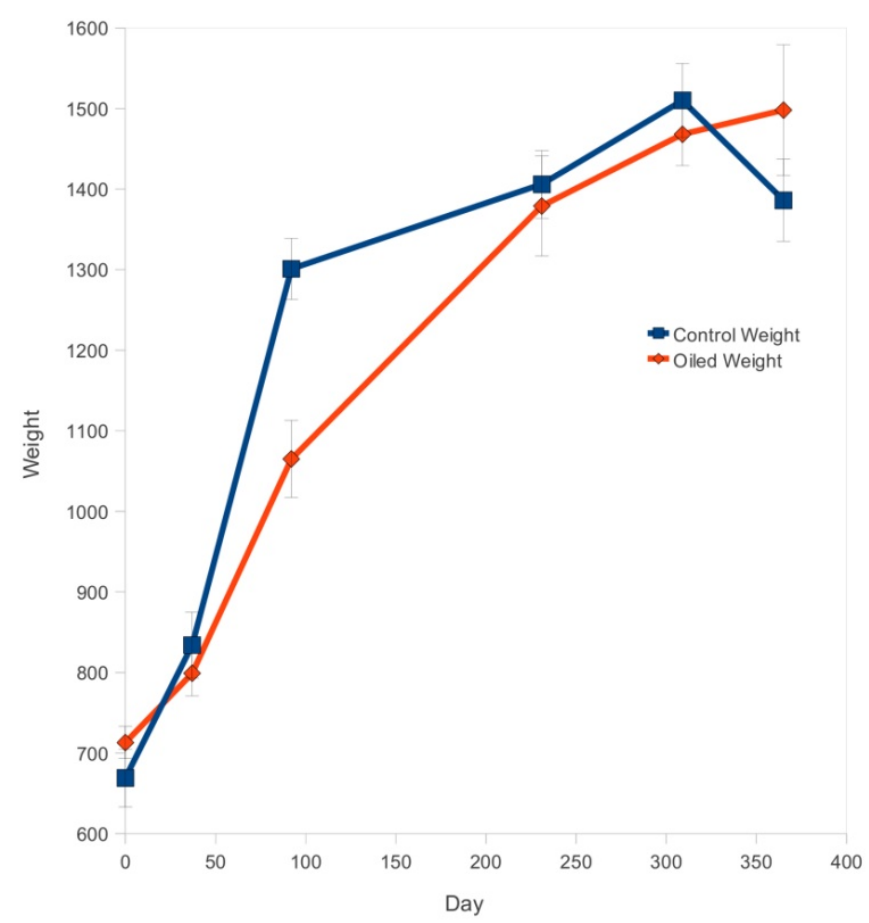

Figure 1. Comparison of mean weight gained in sexually mature Atlantic cod exposed to water-accommodated fractions (WAFs) of crude oil (90 days) and depurated (287 days) subsequently and a control group

Note that the weight was significantly greater in the control than in the WAFs-exposed group after 90 days.

Toxicopathic lesions occurred in the gills of Atlantic cod exposed to WAFs but were rare or absent in the controls. While slight hyperplasia, composed of mesenchymal cells, was restricted to an increase of one cell layer in thickness and not widespread in occurrence in the controls, it varied from moderate to excessive and was widely distributed in the secondary branchial lamellae including the interlamellar spaces of the oil-treated fish. Moreover, hyperplasia of adjacent secondary lamellae resulted in fusion that occurred at intervals of each branchial arch. In addition to thickening of the lamellae and an excessive secretion of mucus covering them, there was evidence of capillary dilation and fibrosis where cellular damage occurred.

\section{Discussion}

The present study has revealed that long term exposure of sexually mature Atlantic cod to sublethal levels of PAHs disrupted gonadal growth and delayed spawning and spermiation. Weight increment, necessary for accumulation of liver lipids that are critical for reproduction, was impaired in some instances and probably associated with reduced feed intake in WAF-treated fish as reported in another study (Kiceniuk \& Khan, 1987). Sex and treatment interaction was also apparent in the summer-autumn WAF-exposed periods. Moreover, GSIs were significantly lower in both female and male WAF-treated cod than in controls during summer to autumn exposure. These differences were also apparent during development of the oocytes and spermatocytes in the ovaries and testes respectively. Oocytes and spermatocytes were consistently larger in the controls than in the WAF-exposed groups. Additionally, while atretic and post-ovulatory follicles occurred in other controls in spring, maturing follicles characterized the WAF-exposed cod. In one experiment (number 6) in which the cod were exposed for 38 days, differences in cellular development in the gonads between controls and WAS-exposed groups were not apparent. A previous study reported differences only in males probably as a result of a paucity of females studied (Kiceniuk \& Khan, 1987). This discrepancy was unavoidable since morphological differences are sometimes indistinguishable between the sexes during selection for the study (W. Scott \& M. Scott, 1988). 
Since induction of gonadal development occurs in cod in autumn, as noted in the present study, it is probable that chronic exposure to PAHs prior to this time disrupted the release of reproductive hormones. Endocrine disruption causing impaired gonadal development has also been reported previously in fish living under the influence of some persistent organic pollutants (Bugel et al., 2010).

Depuration of Atlantic cod exposed between mid-autumn to spring after exposure to low levels of WAFs did not appear to alter the effects on gonadal growth. However, oocyte development, spawning and most likely recrudescence were affected despite removal of the cod from oil-contaminated water after short- or long-term exposure. Moreover, chronic exposure to WAFs for 90 days and depuration subsequently for 287 days resulted in delayed spawning and spermiation. Initially, the WAFs-exposed fish gained less weight during the exposure than the controls but subsequently exhibited similar percent weight gain as the controls. Additionally, pre-spawning behavioral responses of both sexes observed in control fish were absent in the PAH-exposed group. These results suggest that both vitellogenesis and spermatogenesis accompanied by pre-spawning behavior were disrupted after exposure to the PAHs even after depuration. Some organic compounds such as PAHs can disrupt gonadotrophic hormones that are responsible for gonadal development and subsequent release of sex steroids from these organs (Kime, 1995; Nicolas, 1999). Since the abdomens of five of the control cod in one experiment (number 7) were not distended and lacked spawn after compression, it is likely that skipped spawning had occurred. This has been reported previously in wild cod captured and examined during winter off the northeastern coast of Newfoundland (Rideout et al., 2000). Failure of the depurated WAFs-exposed Atlantic cod to ovulate during the spawning period in April could have a profound influence on cod populations in the Newfoundland offshore where two drill riggs are currently removing crude oil from the ocean-bed. Moreover, a decline of GSI in females will result in decreased fecundity and possibly fertility. Future studies should focus on egg counts, egg viability and larval survival while in males, sperm counts and viability will be a prerequisite.

Toxicopathic lesions, observed in the gills of Atlantic cod after chronic exposure to WAFs in the present study, have been reported previously (Khan \& Kiceniuk, 1984). Moreover, these lesions have been observed in fish following long-term exposure to a variety of anthropogenic pollutants including effluent discharged by pulp and paper mills (Khan et al., 1994). Thickening of the secondary branchial lamellae by the WAFs could impair oxygen exchange, induce the gasping response observed and reduce mobility of cod in the water column. Cod actively seek out their prey and escape from predators on account of their swimming speed (W. Scott \& M. Scott, 1988). WAFs have been reported previously to cause a reduction in swimming speed, decreased muscle glycogen and osmoregulatory disruption in juvenile Pacific herring (Clupea pallusi) (Kennedy \& Farrell, 2006). A decline in oxygen exchange and swimming speed could, therefore, affect not only feeding of cod but also escape from its predators, especially seals (Phoca spp.), that are numerous in Newfoundland waters.

Atlantic cod as a demersal species can potentially be affected by spills and seeps where oil drilling operations occur. A previous study has reported toxicopathic lesions in benthic fish sampled in an adjacent area on the Grand Banks off Newfoundland where bilge water was disposed by fishing vessels for many years (Khan, 2000). When a surface or benthic spill of crude oil occurs, its dispersal on concentration and effects will hinge on the quantity released, its latitudinal location and time of the year in relation to water temperature, sunlight and turbulence. On sunny days, turbulent seas and in warm water, photo-oxidation will enhance evaporation and reduce the impact of the WAFs but persistence of the slick, continuously releasing the PAHs, will continue to pose a hazard to aquatic animals especially in subtidal areas (Lee \& Page, 1997; Rice et al., 2001; Jewett et al., 2002; Peterson et al., 2003). However, in frigid subarctic waters, decomposition of PAHs will likely progress more slowly than in warmer conditions and, consequently, persist for longer periods as noted following the spill from the Exxon Valdez in Alaska (Jewett et al., 2002; Rice et al., 2007; Short et al., 2007). Oil spilled in the Gulf of Alaska in 1989 still persists after many years in an unweathered state in mussel (Mytilus edulis) beds and in sediment trapped in semi-enclosed bays (Peterson et al., 2003; Rice et al., 2007). Norcross et al. (1996) observed significantly higher egg-larval mortality, low larval growth rate and morphological and cytological deformations in Pacific herring (Clupea pallast) in oil-contaminated locations compared to samples taken from pristine sites. Most of the damage from the spill occurred in the spawning and nursery grounds of the herring and salmonids in intertidal and subtidal zones. A decline in herring populations coincided with the oil spill over a 5-year period and resulted in closure of the fishery (Thorne \& Thomas, 2008). Herring is a major food source for many species of seabirds and also marine mammals and demise of its populations has culminated in a cascading effect on its predators. The oil-contaminated sediment also poses a threat to other species as Moles and Norcross (1998) have reported reduced growth, $34-56 \%$, in juvenile flatfish exposed to oil-contaminated sediment. Additionally, fin erosion, liver lipidosis, gill hyperplasia and increased gill parasitism were observed in the flatfish. Some similar observations on toxicopathic lesions have been reported in the present and other studies (Khan \& Kiceniuk, 
1984). Consequently, an oil spill could have severe repercussions on survival of the inshore fishery and ultimately on seabird and marine mammal populations.

In conclusion, chronic exposure of sexually mature Atlantic cod to low levels of WAFs affected weight gained, induced toxicopathic lesions and disrupted gonadal development. Fish that were depurated after short and long-term exposure also exhibited lesions, delayed gonadal development, delayed spawning and spermiation. Consequently, a major oil spill could potentially disrupt reproduction in Atlantic cod. Future studies linking THCs with altered oxygen exchange that could occur following damage to the gills and endocrine levels to assess toxic effects on reproduction would be useful in predicting the potential impact of spills on cod population levels.

\section{Acknowledgements}

This study was supported by the Strategic Program of the Natural Sciences \& Engineering Council of Canada and facilities provided by the Ocean Sciences Centre, Memorial University of Newfoundland. I am grateful to several students and colleagues for assistance in the laboratory, Ms. S. Wall for preparation of the manuscript, Dr. P. Earle for the figure and Dr. A. Moles, NOAA, Juneau, Alaska for reviewing the manuscript.

\section{References}

Barron, M. G., Cads, M. G., Heintz, R., \& Rice, S. D. (2004). Evaluation of fish early life-stage to toxicity models of chronic embryonic exposures to complex polycyclic aromatic hydrocarbon mixtures. Toxicological Science, 78, 60-67. http://dx.doi.org/10.1093/toxsci/kfh051

Bugel, S. M., White, L. A., \& Cooper, K. R. (2010). Impaired reproductive health of Killifish (Fundulus heteroclitus) inhabiting Neward Bay, NJ, a chronically contaminated estuary. Aquatic Toxicology, 96, 182-193. http://dx.doi.org/10.1016/j.aquatox.2009.10.016

Evanson M., \& Van Dear Kraak, G. J. (2001). Stimulatory effects of selected PAHs on testosterone production in goldfish and rainbow trout and possible mechanism of action. Comparative Biochemistry and PhysiologPart C: Toxicology \& Pharmacology, 130, 249-258. http://dx.doi.org/10.1016/S1532-0456(01)00246-0

Fletcher, G. L., King, M. J., Kiceniuk, J. W., \& Addison, R. F. (1982). Liver hypertrophy in winter flounder following exposure to experimentally oiled sediments. Comparative Biochemistry and Physiolog-Part C: Toxicology \& Pharmacology, 73C, 459-462.

Jewett, S. C., Dean, T. A., Woodin, B. R., Hoberg, M. K., \& Stegeman, J. J. (2002). Exposure to hydrocarbons 10 years after the Exxon Valdez oil spill: evidence from cytochrome P450IA expression and biliary FACs in nearshore demersal fishes. Marine Environmental Research, 54, 21-48. http://dx.doi.org/10.1016/S0141-1136(02)00093-4

Kennedy, C. J., \& Farrell, A. P. (2006). Effects of exposure to the water-soluble fraction of crude oil on the swimming performance and the metabolic and ionic recovery post exercise in Pacific herring (Clupea pallasi). Environmental Toxicology and Chemistry, 25, 2715-2724. http://dx.doi.org/10.1897/05-504R.1

Khan, R. A. (1987). Effect of chronic exposure to petroleum hydrocarbons on two species of marine fish infected with a hemoprotozoan, Trypanosoma murmanensis. Canadian Journal of Zoology, 65, 2703-2709. http://dx.doi.org/10.1139/z87-410

Khan, R. A. (1991). Effect of oil contaminated sediment on the longhorn sculpin (Myoxocephalus octodecemspinosus) following chronic exposure. Bulletin of Environmental Contamination and Toxicology, 47, 63-69. http://dx.doi.org/10.1007/BF01689454

Khan, R. A. (2000). Comparison of tissue lesions in four species of benthic fish sampled in 1972-1973and 1997-1998 on the Grand Banks off Newfoundland. Bulletin of Environmental Contamination and Toxicology, 65, 78-83. http://dx.doi.org/10.1007/s001280000097

Khan, R. A., \& Kiceniuk, J. W. (1984). Histopathological effects of crude oil on Atlantic cod following chronic exposure. Canadian Journal of Zoology, 62, 2038-2043. http://dx.doi.org/10.1139/z84-298

Khan, R. A., Barker, D. E., Hooper, R., Ryan, K., \& Nag, K. (1994). Histopathology in winter flounder (Pleuronectes americanus) living adjacent to a pulp and paper mill. Archives of Environmental Contamination and Toxicology, 26, 95-102. http://dx.doi.org/10.1007/BF00212799

Khan, R. A., \& Payne, J. F. (2005). Influence of a crude oil dispersant, Corexit 9627 and dispersed oil on capelin (Mallotus villosus), Atlantic cod (Gadus morhua), longhorn sculpin (Myoxocephalus octodecomspinosus) and 
cunner (Tautogolabrus adspersus). Bulletin of Environmental Contamination and Toxicology, 75, 50-56. http://dx.doi.org/10.1007/s00128-005-0717-9

Kiceniuk, J. W., \& Khan, R. A. (1987). Effect of petroleum hydrocarbons on Atlantic cod, Gadus morhua, following chronic exposure. Canadian Journal of Zoology, 65, 490-495. http://dx.doi.org/10.1139/z87-076

Kime, D. F. (1995). The effects of pollution on reproduction in fish. Review. Fish Biology and Fisheries, 5, 52-96. http://dx.doi.org/10.1007/BF01103366

Lee, R. F., \& Page, D. S. (1997). Petroleum hydrocarbons and their effects in subtidal regions after major oil spills. Marine Pollution Bulletin, 31, 928-940. http://dx.doi.org/10.1016/S0025-326X(97)00078-7

Lyons, M. C., Wong, D. K. H., Mulder, I., Lee, K., \& Burridge, L. E. (2011). The influence of water temperature on induces liver EROD activity in Atlantic cod (Gadus morhua) exposed to crude oil and oil dispersants. Ecotoxicology and Environmental Safety, 74, 904-910. http://dx.doi.org/10.1016/j.ecoenv.2010.12.013

Moles, A., \& Norcross, B. L. (1998). Effects of oil-laden sediment on growth and health of juvenile flatfishes. Canadian Journal of Fisheries and Aquatic Sciences, 55, 605-610. http://dx.doi.org/10.1139/f97-278

Nicolas, J. M. (1999). Vitellogenesis in fish and the effects of polcyclic aromatic hydrocarbon contaminants. Aquatic Toxicology, 45, 77-90. http://dx.doi.org/10.1016/S0166-445X(98)00095-2

Norcross, B. L., Hose, J. E., Frandsen, M., \& Brown, E. D. (1996). Distribution, abundance, morphological condition, and cytogenetic abnormalities of larval herring in Prince William Sound, Alaska, following the Exxon Valdez Oil Spill. Canadian Journal of Fisheries and Aquatic Sciences, 53, 2376-2387.

Payne, J. F., Kiceniuk, J. W., Squires, W. R., \& Porter, E. L. (1978). Pathological changes in a marine fish after a six-month exposure to petroleum. Journal of the Fisheries Research Board of Canada, 35, 665-667. http://dx.doi.org/10.1139/f78-116

Peterson, C. H., Rice, S. D., Short, J. W., Esler, D., Bodkin, J. L., Ballachey, B. E., \& Irons, D. B. (2003). Long-term ecosystem response to the Exxon Valdez oil spill. Science, 302, 2082-2086. http://dx.doi.org/10.1126/science.1084282

Rice, S. D., Thomas, R. E., Carls, M. G., Heintz, R. A., Wertheimer, A. C., Murphy, M. L., ... Moles, A. (2001). Impacts to pink salmon following the Exxon Valdez oil spill: persistence, toxicity, sensitivity, and controversy. Reviews in Fishery Science, 9, 165-211. http://dx.doi.org/10.1080/20016491101744

Rice, S. D., Short, J. W., Carls, M. G., Moles, A., \& Spies, R. B. (2007). The Exxon Valdez oil spill. In: Long-term ecological change in the northern Gulf of Alaska. Ed., R. B. Spies, T. Cooney, A. M. Springer, T. Weingartner, \& G. Kruse. Amsterdam: Elsevier Publications, $413-514$. http://dx.doi.org/10.1016/B978-044452960-2/50006-0

Rideout, R. M., \& Rose, G. A. (2006). Suppression of reproduction in Atlantic cod Gadus morhua. Marine Ecology Progress Series, 320, 267-277. http://dx.doi.org/10.3354/meps320267

Rideout, R. M., Burton, M. P. M., \& Rose, G. A. (2000). Observations on mass atresia and skipped spawning in northern Atlantic cod, from Smith Sound, Newfoundland. Journal of Fish Biology, 57, 1429-1440. http://dx.doi.org/10.1111/j.1095-8649.2000.tb02222.x

Scott, W. B., \& Scott, M. G. (1988). Atlantic fishes of Canada. Canadian Bulletin of Fisheries and Aquatic Sciences, 219, 731 .

Short, J. W., Irvine, G. V., Mann, D. H., Maselko, J. M., Pella, J. J., Lindenberg, M. R., ... Rice, S. D. (2007). Slightly weathered Exxon Valdez oil persists in Gulf of Alaska beach sediments after 16 years. Environmental Science and Technology, 41, 1246-1250. http://dx.doi.org/10.1021/es0620033

Sol, S. Y., Johnson L. L., Horness, B. H., \& Collier, T. K. (2000). Relationship between oil exposure and reproduction parameters in fish collected following the Exxon Valdez oil spill. Marine Pollution Bulletin, 40, 1139-1147. http://dx.doi.org/10.1016/S0025-326X(00)00074-6

Sutcliffe, W. H. Jr., Loucks, R. H., Drinkwater, K. F., \& Coote, A. R. (1983). Nutrient flux onto the Labrador shelf from Hudson Strait and its biological consequences. Canadian Journal of Fisheries and Aquatic Sciences, 40, 1692-1701. http://dx.doi.org/10.1139/f83-196

Templeman, W. (1974). Migration and intermingling of Atlantic cod, Gadus morhua, stocks of the Newfoundland area. Journal of the Fisheries Research Board of Canada, 31, 1073-1092. http://dx.doi.org/10.1139/f74-122 
Tetreault, G. R., Mcmaster, M. E., Dixon, D. G., \& Parrott, J. L. (2009). Using reproductive endpoints in small forage fish species to evaluate the effects of athabasca oil sands activities. Environmental Toxicology and Chemistry, 22, 2775-2782. http://dx.doi.org/10.1897/03-7

Thorne, R. E., \& Thomas, G. L. (2008). Herring and the "Exxon Valdez" oil spill: an investigation into historical data conflicts. ICES Journal of Marine Science, 65, 44-50. http://dx.doi.org/10.1093/icesjms/fsm176

Truscott, B., Walsh, J. W., Burton, M. P., Payne, J. F., \& Idler, D. R. (1983). Effect of acute exposure to crude petroleum on some reproductive hormones in salmon and flounder. Comparative Biochemistry and Physiology - Part C: Comparative Pharmacology, 75, 121-130. http://dx.doi.org/10.1016/0742-8413(83)90020-8

Tuvikene, A. (1995). Responses of fish to polycyclic aromatic hydrocarbons (PAHs). Annales Zoologici Fennici., 32, 295-309. 